\title{
Design of Blessing Ball Throwing Techniques for KRAI 2018 Robot
}

\section{Perancangan Teknik Pelempar Bola Berkah pada Robot KRAI 2018}

\author{
Rochmat Diantoro', Wahyu Sapto Aji ${ }^{1,2}$ \\ ${ }^{1}$ Universitas Ahmad Dahlan, Indonesia \\ ${ }^{2}$ Universiti Malaysia Pahang, Malaysia
}

\section{INFORMASI ARTIKEL}

\section{Riwayat Artikel:}

Dikirimkan 07 Agustus 2020,

Direvisi 28 September 2020,

Diterima 28 September 2020.

\section{Kata Kunci:}

Robot Abu Robocon,

Pneumatik,

Arduino,

Sudut Kemiringan,

Pelempar Bola Berkah.

\section{Penulis Korespondensi:}

Wahyu Sapto Aji, Teknik Elektro, Universitas Ahmad Dahlan, Kampus IV, Jl. Ring Road Selatan, Tamanan, Banguntapan, Bantul Yogyakarta 55166 Surel:wahyusaji@ee.uad.ac.id

\section{ABSTRACT / ABSTRAK}

Abu Robocon 2018 which was held in Vietnam with the theme "nem con" which means throwing a berkah ball. The Indonesia Abu Robot Contest 2018 made a throwing robot design with different pole height. The parameter that must be achieved is the optimization of the throwing mechanical drive. The thrower mechanics in the KRAI robot can use pneumatically by determining the angle of the robotic thrower. The mechanical tilt angle determines the throwing distance of the berkah ball. To find out the height of this research berkah ball will use python to display the parabolic motion. Based on the results of the study obtained the first test results with a throwing angle of $0{ }^{\circ}$ $115^{\circ}$ get an average value of a distance of $7.37 \mathrm{~m}$, height $273.4 \mathrm{Cm}$, time 1.42 $s$ and speed of $5.152 \mathrm{~m} / \mathrm{s}$. The results of the two test with a throwing angle of $0^{\circ}-95^{\circ}$ obtained an average distance of $8.78 \mathrm{~m}$, height $352.4 \mathrm{Cm}$, time $1.63 \mathrm{~s}$ and speed $5.381 \mathrm{~m} / \mathrm{s}$. It can be concluded that the mechanical tilt angle is leaned forward, the pitching results will be lower. When the angle of inclination is tilted backwards the berkah ball will soar more.

Abu Robocon 2018 yang diselenggarakan di negara Vietnam dengan tema "nem con" yang artinya lempar bola berkah. Kontes robot abu Indonesia 2018 membuat perancangan robot pelempar dengan tinggi tiang yang berbeda-beda. Parameter yang harus dicapai yaitu pengoptimalan penggerak mekanik pelempar. Mekanik pelempar pada robot KRAI dapat menggunakan pneumatik dengan menentukan sudut kemiringan pelempar robot. Sudut kemiringan mekanik menentukan jarak pelemparan bola berkah. Untuk mengetahui tinggi bola berkah penelitian ini akan menggunakan python untuk menampilkan gerak parabola. Berdasarkan hasil penelitian didapatkan hasil pengujian pertama dengan sudut pelempar $0^{\circ}-115^{\circ}$ mendapatkan nilai rata - rata jarak 7,37 m, tinggi $273,4 \mathrm{Cm}$, waktu $1,42 \mathrm{~s}$ dan kecepatan $5,152 \mathrm{~m} / \mathrm{s}$. Hasil pengujian kedua dengan sudut pelempar $0^{\circ}-95^{\circ}$ di dapatkan rata - rata jarak 8,78 m, tinggi 352,4 Cm, waktu 1,63 s dan kecepatan 5,381 m/s. Dapat disimpulkan bahwa sudut kemiringan mekanik dicondongkan ke depan maka hasil pelemparan akan semakin rendah. Ketika sudut kemiringan dicondongkan ke belakang maka bola berkah akan semakin melambung.

This work is licensed under a Creative Commons Attribution-Share Alike 4.0

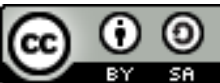

\section{Sitasi Dokumen ini:}

Rochmat Diantoro and W. S. Aji "Design of Blessing Ball Throwing Techniques for KRAI 2018 Robot," Buletin Ilmiah Sarjana Teknik Elektro, vol. 2, no. 3, pp. 119-129, 2020. DOI: 10.12928/biste.v2i3.2623 


\section{PENDAHULUAN}

Kontes robot abu Indonesia tahun 2018 diadakan oleh DIKTI, robot KRAI 2018 mengusung tema lempar bola berkah. Perancangan robot KRAI 2018 dituntut membuat robot pelempar dengan akurat, dengan mengacu peraturan Abu Robocon. Robot adalah sebuah mesin yang menggabungkan mekanik dan elektronik yang terkontrol secara otomasi atau dengan bantuan seorang operator sehingga dapat menggantikan manusia dalam membantu pekerjaan.

Misi robot KRAI 2018 adalah melempar bola berkah ke dalam ring sesuai peraturan Abu robocon. Robot KRAI terdiri dari robot manual dan otomatis. Setelah menerima bola berkah dari robot manual, maka robot otomatis bertugas melempar bola berkah ke ring yang telah ditentukan, ada tiga titik tempat robot untuk melemparkan bola berkah. Tiga titik tersebut diberi nama throwing zone 1, throwing zone 2 dan throwing zone 3 [1]. Bola berkah yang digunakan sudah ditentukan oleh ABU Robocon, jumlah bola yang digunakan sebanyak 10 bola. Untuk tiang $300 \mathrm{Cm}$ menggunakan bola berkah berwarna emas sebanyak 5 bola. Terdapat nampan atau semacam wadah dengan diamater $120 \mathrm{Cm}$ yang letaknya segaris lurus dengan tiang yang tingginya $300 \mathrm{Cm}$. Apabila robot berhasil melemparkan bola berwarna emas dan berhasil memasuki sasaran tiang dengan tinggi $300 \mathrm{Cm}$. Ketika robot berhasil memasukkan bola ke nampan maka tim akan dinyatakan sebagai pemenang dalam pertandingan. Robot KRAI 2018 dibuat menggunakan robot dengan roda omniwheel yang memiliki keunggulan dalam bergerak dikarenakan memiliki kebebasan dalam bergerak yaitu pada sumbu $x$ dan sumbu $y$. Desain robot KRAI menggunakan 2 jenis robot omniwheel dengan menggunakan 3 roda dan 4 roda [2]. Poin utama untuk memenangkan pertandingan di Abu robocon 2018 adalah efisiensi sudut robot untuk menembakkan atau mengarahkan bola ke target pada area pertandingan. Robot dibuat sistem untuk mengarahkan robot ke sudut yang benar dengan rotasi posisi. Sehingga robot dapat berhenti tepat pada sudut yang sudah ditentukan [3].

Perancangan robot ini diharapkan robot bergerak secara efektif dengan lapangan yang tidak rata, perancangan robot $\mathrm{ABU}$ memanfaatkan tekanan angin untuk melemparkan bola berkah [4]. Fokus $\mathrm{ABU}$ Robocon untuk target menciptakan robot dengan teknologi inovatif. Pembuatan robot seperti desain mekanik, perancangan elektronik, dan perancangan program dapat dikembangkan sebagai pengajaran di kelas [5].

\section{METODE PENELITIAN}

Kontes robot abu Indonesia tahun 2018 akan merancang robot pelempar bola dengan menggunakan sistem pneumatik. Robot akan menggunakan 2 sistem pelempar dengan sasaran tiang dengan tinggi yang berbedabeda. Sistem mikrokontroller pada robot menggunakan arduino mega untuk mengontrol relai yang akan memberikan tegangan DC ke solenoid.

\subsection{Gerak Parabola}

Abu Robocon 2018 dengan tema lempar bola berkah, hasil penelitian yang dilakukan menghasilkan percepatan gravitasi mempengaruhi gerak suatu benda, salah satunya adalah pada gerak parabola. Gerak parabola merupakan suatu jenis gerakan benda yang awalnya diberi kecepatan awal kemudian menempuh lintasan yang arah sepenuhnya dipengaruhi oleh gravitasi sehingga lintasan tersebut berbentuk parabola[6]. Gerak parabola dapat dilihat pada Gambar 1.

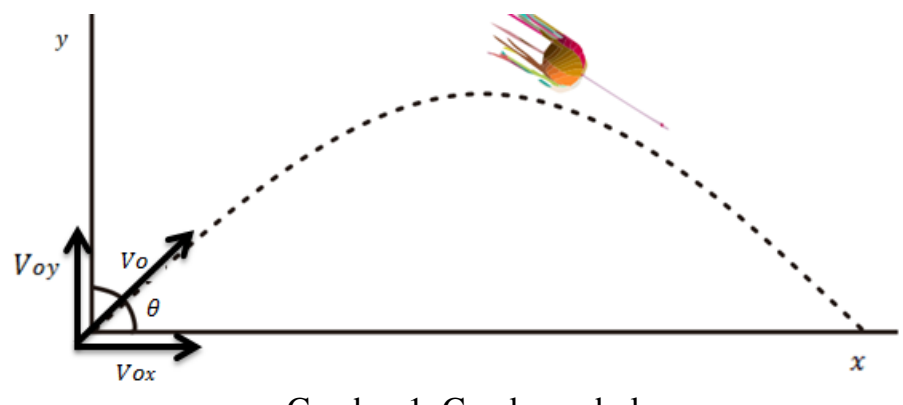

Gambar 1. Gerak parabola

Gerak pada sumbu-y yaitu gerak lurus berubah beraturan pada arah vertikal. Gerak benda pada arah vertikal yang dipengaruhi oleh gaya gravitasi, sehingga ada perlambatan pada arah ini. Gerak pada sumbu-x yaitu gerak lurus beraturan, yaitu gerak benda pada arah mendatar yang tidak dipengaruhi oleh gaya gravitasi, sehingga tidak ada percepatan atau perlambatan pada arah ini [7]. Kecepatan awal benda disetiap titik bernilai konstan dan berlaku persamaan:

$$
V o x=V o \cos \theta
$$

Jarak mendatar yang ditempuh oleh posisi benda setiap waktu dapat ditentukan oleh persamaan: 


$$
x=V o \cos \theta t
$$

Keterangan:

Vo $\quad=$ Kecepatan awal $(\mathrm{m} / \mathrm{s})$

$t \quad=$ Waktu $(\mathrm{s})$

$\theta \quad=$ Sudut kemiringan $\left({ }^{\circ}\right)$

\subsection{Desain Robot}

Perancangan robot akan mengacu pada peraturan ABU Robocon 2018, perancangan robot meliputi perancangan mekanik, perancangan elektronik, dan perancangan program. Mekanik robot dibuat dengan bahan dasar steanless sehingga frame robot kuat tidak mudah patah. Mekanik pelempar dibuat 2 tuas pelempar dengan spesifikasi panjang yang berbeda-beda. Sistem elektronik robot menggunakan Arduino mega untuk mengontrol LCD 16x2 sebagai visual kondisi robot, Relai untuk memberikan tegangan DC ke solenoid. Sensor IR akan dipasang pada robot untuk mendeteksi bola sebagai pemicu untuk melakukan lemparan bola. pneumatik merupakan salah satu pengganti motor DC yang tepat. Karena pneumatik menggunakan udara sebagai penggeraknya, sehingga pergerakan pneumatik sangat cepat. Aplikasi silinder pneumatik yaitu kontrol posisi, dimana piston silinder pneumatik hanya bisa berhenti pada ujung-ujung silinder. Silinder aksi ganda adalah kedua ujungnya dihubungkan dengan sumber udara bertekanan kemudian menyeimbangkan tekanan udara yang masuk pada kedua sisi silinder pneumatik [8].

Desain pelempar robot KRAI tahun 2018 menggunakan solidwork untuk membuat gambar 3 dimensi. Perancangan desain 3 dimensi memudahkan dalam bentuk fisik aslinya. Robot menggunakan 2 tuas pelempar dengan spesifikasi pelempar I dilihat Gambar 2 menggunakan sudut 110 dan pelempar II dilihat Gambar 3 menggunakan sudut 90 .

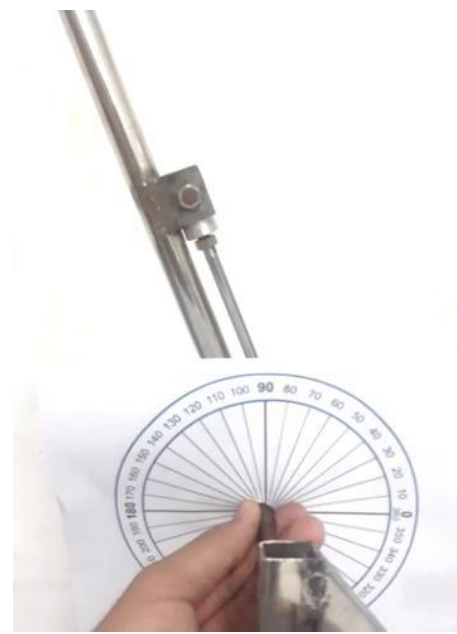

Gambar 2. Sudut kemiringan pelempar I.

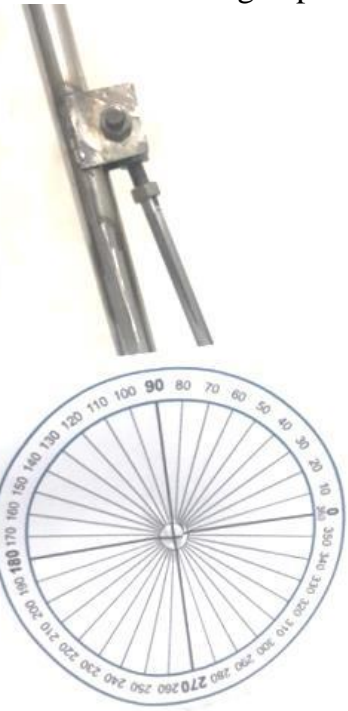

Gambar 3. Sudut kemiringan pelempar II. 


\subsection{Proses Kerja Robot}

Sensor IR untuk mendeteksi objek bola berkah yang sudah diterima dari robot manual. Arduino mega yang menjadi mikrokontroler robot KRAI 2018 untuk mengendalikan robot lebih stabil. Mikrokontroller arduino mega akan membutuhkan catu daya $5 \mathrm{~V}$ untuk menyuplai tegangan mikrokontroller. Input pin arduino mega sensor IR sedangkan pin output arduino mega relai. Relai berfungsi memberikan saklar/switch untuk menyuplai tegangan DC ke solenoid robot. Fungsi solenoid pada robot akan mengatur tekanan angin yang menyuplai pneumatik sebagai pelempar. Pneumatik pada robot akan dibuat sudut kemiringan mekanik untuk menghasilkan pelemparan yang diinginkan. Kinerja robot KRAI dengan menggunakan Arduino mega sebagai mikrokontroller. Arduino mega memiliki kelebihan untuk membuat kinerja robot lebih baik dan stabil [9]. Sensor IR ketika tidak mendeteksi objek bola berkah maka memberikan logika 0, kemudian saat sensor IR mendeteksi objek bola berkah maka diberikan logika 1. Setelah sensor IR memberikan logika 1 ke Arduino maka relai dalam keadaan closeloop untuk memberikan tegangan pada solenoid. Gambar 4 ADALAH diagram alir sistem kinerja robot KRAI 2018.

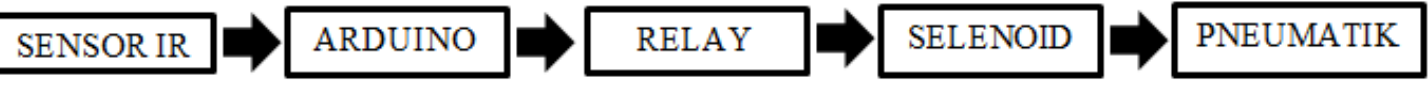

Gambar 4. Diagram sistem kinerja robot.

Robot KRAI 2018 menggunakan pelempar dengan sistem pneumatik. Cara kerja sistem pada pneumatik yaitu angin akan di simpan pada 8 botol big colla yang sudah dimodifikasi. Botol dapat menyimpan tekanan angin sampai $6.0 \mathrm{bar} / \mathrm{Kpa}$. Untuk mengetahui tekanan angin dilihat pada indikator tekanan angin. Input angin dapat digunakan sebagai mengisi tekanan angin dan membuang tekanan angin. Selenoid adalah katup yang digerakkan oleh energi listrik melalui solenoid, mempunyai kumparan sebagai penggeraknya yang berfungsi untuk menggerakkan piston yang dapat digerakkan oleh arus DC. Solenoid valve pneumatik / katup solenoid mempunyai lubang keluaran, lubang masukan dan lubang exhaust. Selenoid pelempar I dan solenoid pelempar II akan mengontrol katup buka angin dan katup tutup angin yang akan sampai pada pneumatik pelempar I dan pneumatik pelempar II. Pneumatik yaitu actuator ball valve mempunyai dua lubang untuk selang angin. Satu selang untuk membuka ball valve dan satu selang lagi untuk menutup ball valve. Cara kerja pneumatik digerakkan dengan tekanan angin yang di simpan pada tabung penyimpan udara. Jenis pneumatik yang digunakan double acting yaitu pneumatik dapat bekerja membuka dan menutupnya ball valve dari kekuatan angin [10]. Sistem pneumatik robot dilihat Gambar 5 piping pneumatik.

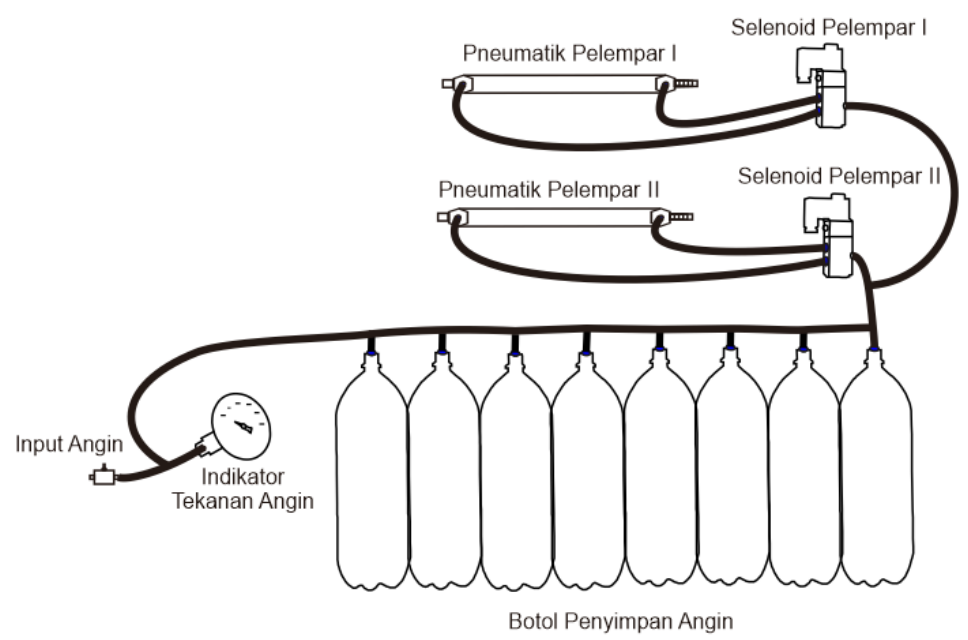

\section{4. Perancangan Program}

Gambar 5. Piping pneumatik.

Robot diprogram ketika salah satu sensor IR mendeteksi adanya bola berkah maka Arduino akan memberikan perintah relai untuk closeloop agar solenoid mendapatkan tegangan $12 \mathrm{v}$. Ketika robot tidak mendeteksi adanya bola berkah maka robot akan menunggu sampai ada objek yang terdeteksi. Robot setelah mendeteksi bola berkah dengan waktu tunggu relai closeloop $10 \mathrm{~m} / \mathrm{s}$. Listing program robot KRAI 2018 dintunjukan pada Gambar 6. 


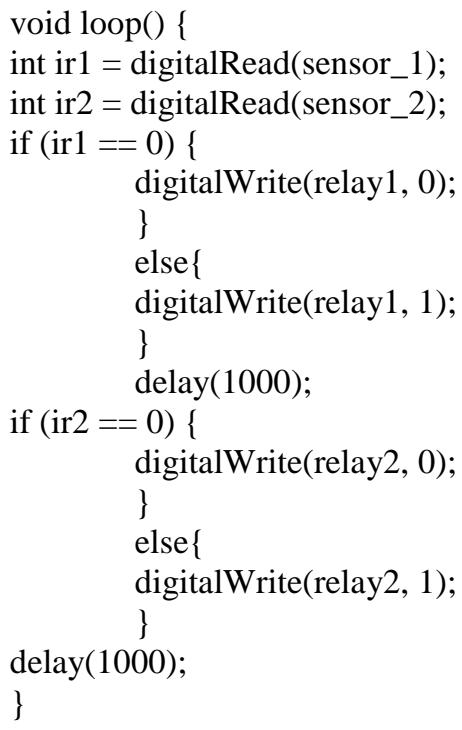

Gambar 6. Listing program robot.

Listing program menunjukkan "int ir1 = digitalRead(sensor_1); dan int ir2 = digitalRead(sensor_2);" untuk melakukan pemanggilan sensor IR yang digunakan mendeteksi objek bola berkah. Logika "if (ir1 == 0)" dan "if (ir2 ==0) "ketika sensor IR I dan IR II tidak mendeteksi objek (logika 0) maka robot akan menunggu sampai adanya objek terdeteksi, ketika sensor IR mendeteksi adanya objek bola berkah maka sensor IR akan mengirim logika 1 dengan lama waktu tunggu selama $10 \mathrm{~m} / \mathrm{s}$ kemudian arduino mega akan memerintahkan robot pada posisi zona lempar.

\subsection{Flowchart}

Flowchart pada robot KRAI untuk memprogram robot dengan menggunakan mikrokontroller Arduino mega. Sensor IR pada robot digunakan sebagai pemicu jalannya robot, ketika robot mendeteksi bola berkah robot akan memosisikan zona lempar. Robot akan melemparkan bola berkah dengan menggunakan relai sebagai saklar solenoid untuk membuka dan menutup angin pada pneumatik double acting. Perancangan flowchart dilihat Gambar 7.

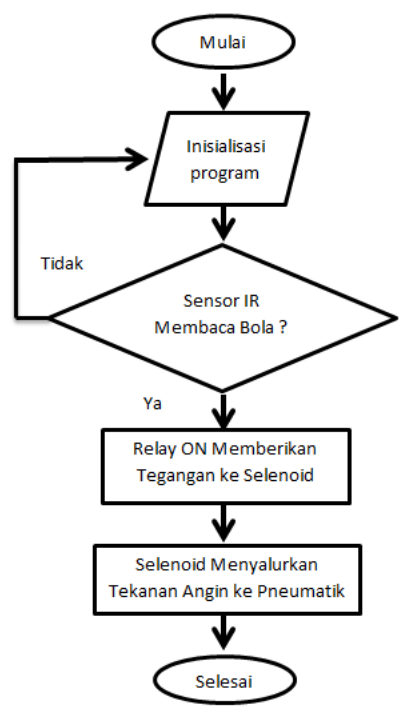

Gambar 7. Flowchart program

\section{HASIL DAN PEMBAHASAN}

Pengujian dilakukan untuk mengetahui hasil pelempar robot mendapatkan hasil yang baik. Setelah dilakukan pengujian I dengan jarak $340 \mathrm{Cm}$, tinggi $200 \mathrm{Cm}$ dan jarak $496 \mathrm{Cm}$, tinggi 300Cm berikut hasil pengujian I dan pengujian II. 


\subsection{Hasil Pengujian 1}

Pengujian kedua dilakukan dengan membuat sudut kemiringan mekanik pada titik lempar menjadi $115^{\circ}$. Sudut kemiringan mekanik mempengaruhi hasil pelemparan. Pengujian pada tiang I yang dilakukan mengambil 5 data percobaan pelemparan bola berkah dengan tinggi tiang $200 \mathrm{Cm}$ dan jarak titik lempar 340 Cm. Berikut hasil pengujian yang dilakukan Gambar 8, Gambar 9, Gambar 10, Gambar 11, dan Gambar 12.

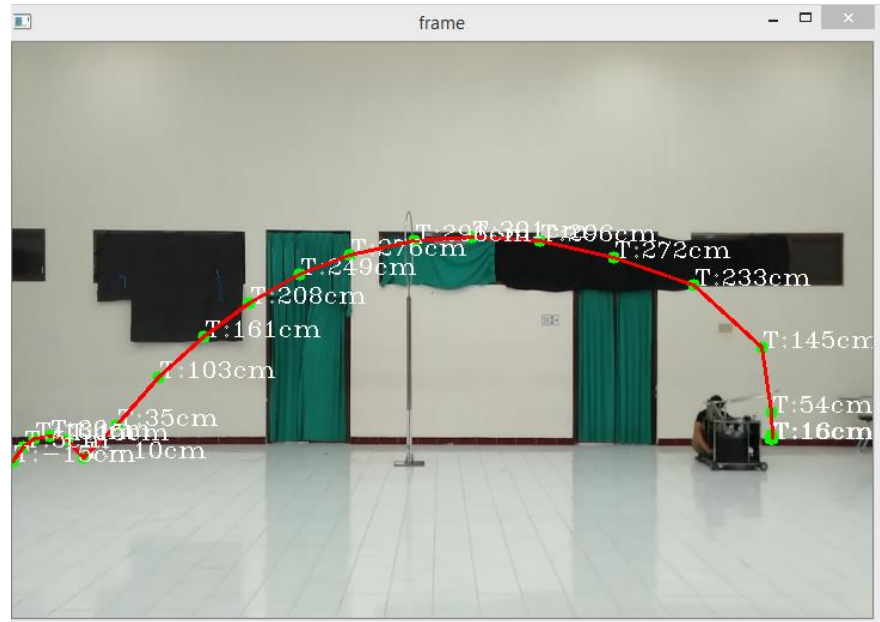

Gambar 8 Pengolahan menggunakan program python ke I.

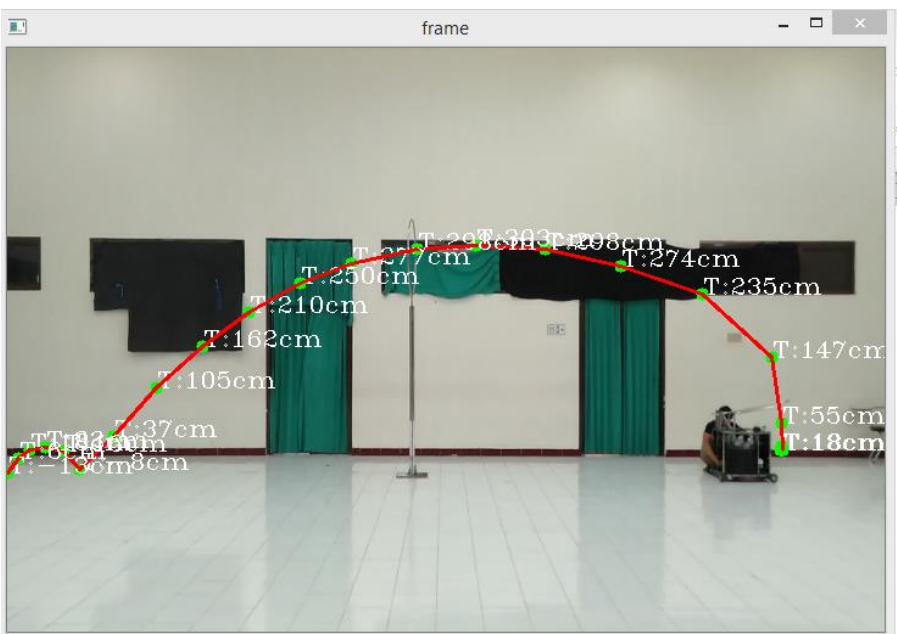

Gambar 9 Pengolahan menggunakan program python ke II

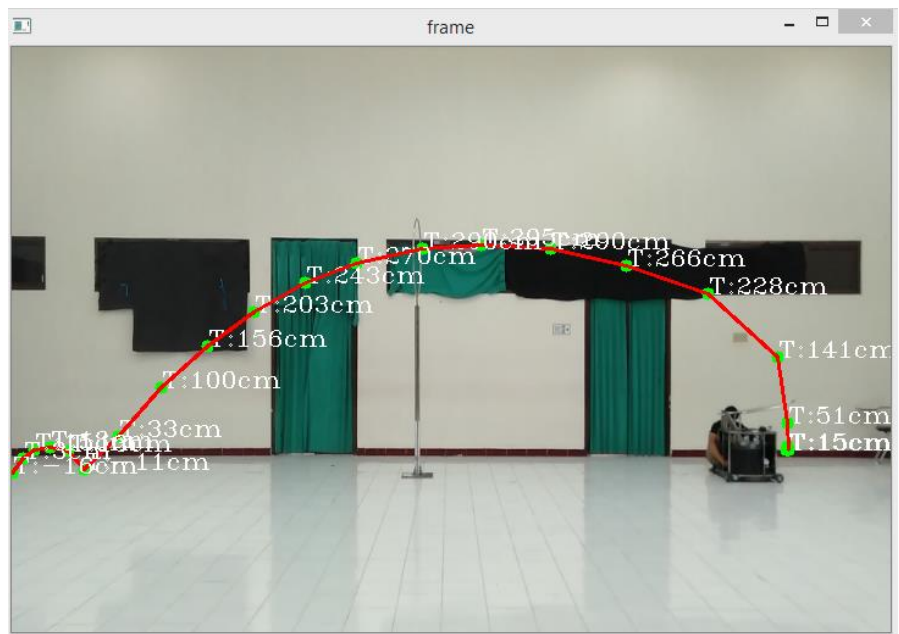

Gambar 10 Pengolahan menggunakan program python ke III. 


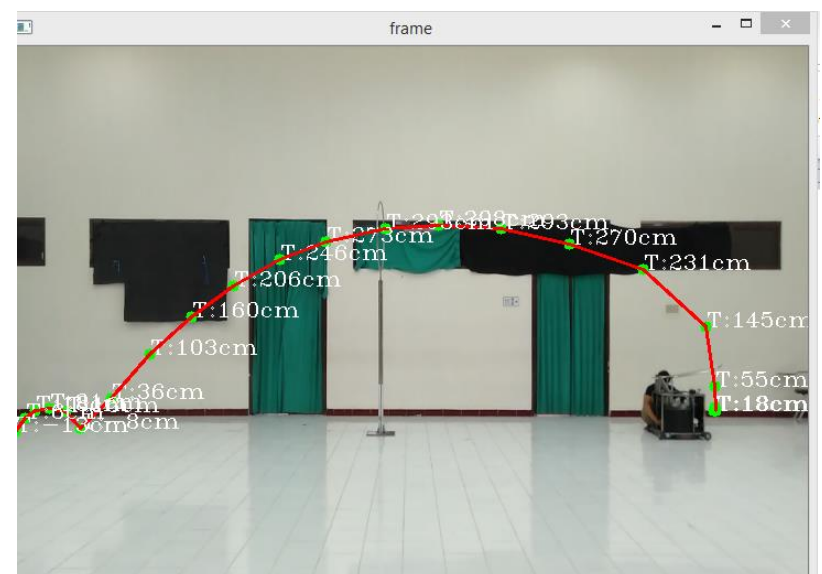

Gambar 11 Pengolahan menggunakan program python ke IV.

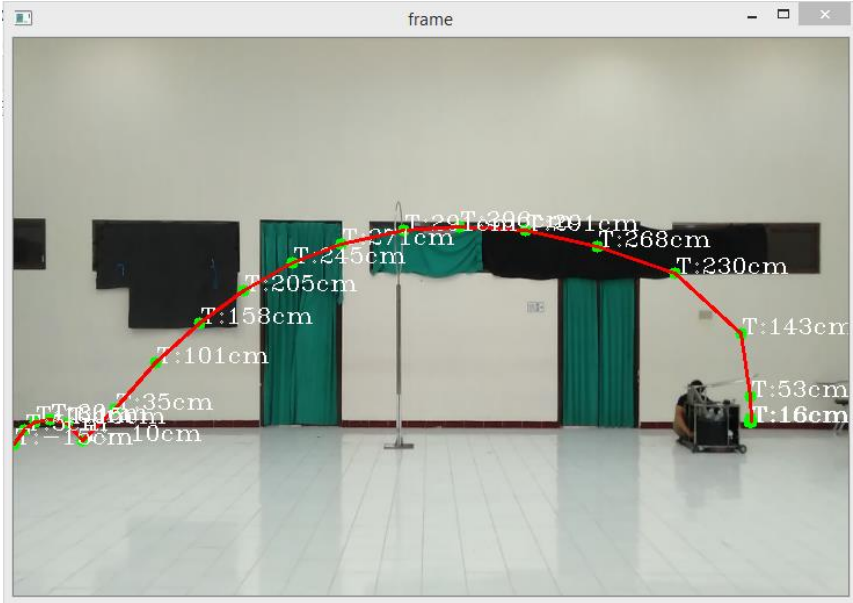

Gambar 12 Pengolahan menggunakan program python ke V.

Hasil perekaman video dengan menggunakan kamera dapat dilihat Gambar di atas. Hasil video kemudian diolah dengan perangkat lunak berbasis aplikasi python untuk melihat hasil gerak parabola. Pengujian dilakukan selama 5 kali percobaan menghasilkan jarak, waktu, dan titik tinggi bola berkah. Hasil pengujian lempar bola berkah berikut tabel hasil percobaan Tabel 1.

Tabel 1. Pengujian data 5 kali percobaan.

\begin{tabular}{|c|c|c|c|c|c|}
\hline No. & $\begin{array}{c}\text { Sudut Kemiringan } \\
(\text { Derajat })\end{array}$ & $\begin{array}{c}\text { Tekanan Angin } \\
(\text { Kpa/bar })\end{array}$ & $\begin{array}{c}\text { Jarak } \\
(\mathrm{Cm})\end{array}$ & $\begin{array}{c}\text { Waktu } \\
(\mathrm{S})\end{array}$ & $\begin{array}{c}\text { Tinggi } \\
(\mathrm{Cm})\end{array}$ \\
\hline 1. & $0^{\circ}-115^{\circ}$ & 5,9 & 7,40 & 1,45 & 276 \\
\hline 2. & $0^{\circ}-115^{\circ}$ & 5,9 & 7,35 & 1,40 & 270 \\
\hline 3. & $0^{\circ}-115^{\circ}$ & 5,9 & 7,35 & 1,42 & 271 \\
\hline 4. & $0^{\circ}-115^{\circ}$ & 5,9 & 7,35 & 1,39 & 273 \\
\hline 5. & $0^{\circ}-115^{\circ}$ & 5,9 & 7,40 & 1,47 & 277 \\
\hline
\end{tabular}

Pengujian pelempar dengan jarak 340Cm dengan ketinggian 200Cm dilakukan selama 5 percobaan. Pengujian dilakukan dengan sudut kemiringan $0^{\circ}-115^{\circ}$ dan tekanan angin yang digunakan 5,9 bar/Kpa dengan percobaan 5 kali pengujian dihasilkan lemparan tepat sasaran selama 5 kali percobaan pada tiang pertama. Untuk mendapatkan hasil pengujian yang maksimal, maka data pengujian selama 5 kali percobaan akan dibuat rata-rata untuk memperoleh penelitian yang baik. Setelah melakukan 5 kali pengujian mendapatkan nilai ratarata hasil pengujian dengan sudut kemiringan $0^{\circ}-115^{\circ}$, jarak $7,37 \mathrm{~m}$, tinggi $273,8 \mathrm{Cm}$, waktu $1,42 \mathrm{~s}$ dan kecepatan $5,152 \mathrm{~m} / \mathrm{s}$.

\subsection{Pengujian 2}

Pengujian kedua dilakukan dengan membuat sudut kemiringan mekanik pada titik lempar menjadi $115^{\circ}$. Sudut kemiringan mekanik mempengaruhi hasil pelemparan. Pengujian akan dilakukan di lapangan yang 
sesuai peraturan KRAI 2018. Pengujian pada tiang II dengan jarak $496 \mathrm{Cm}$ yang dilakukan mengambil 5 data percobaan pelemparan bola berkah dengan tinggi tiang $300 \mathrm{Cm}$. Berikut hasil pengujian yang dilakukan Gambar 13, Gambar 14, Gambar 15, Gambar 16, dan Gambar 17.

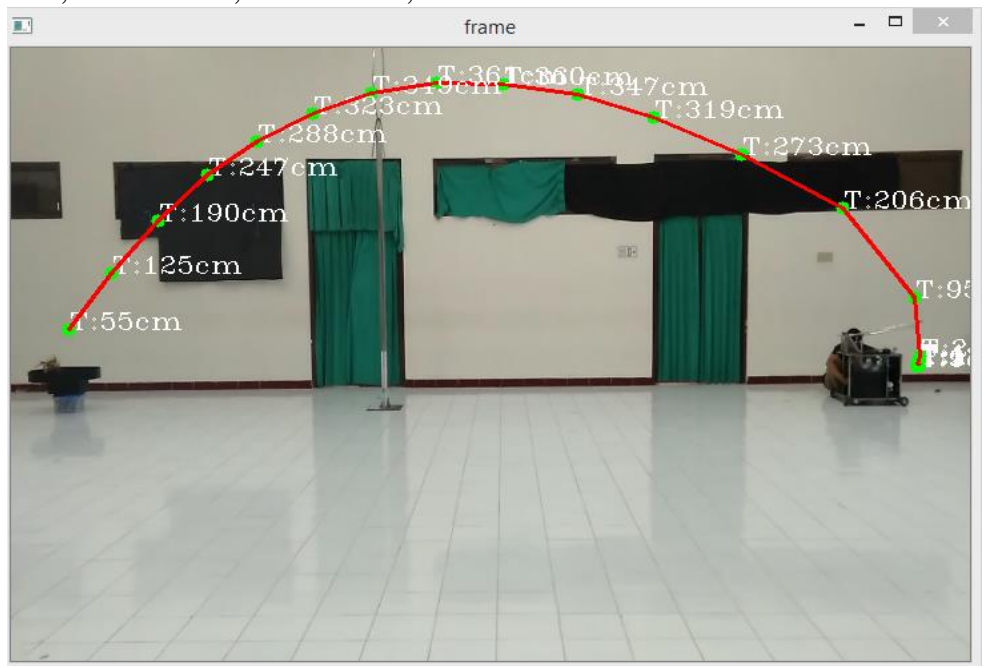

Gambar 13 Pengolahan menggunakan program python ke I

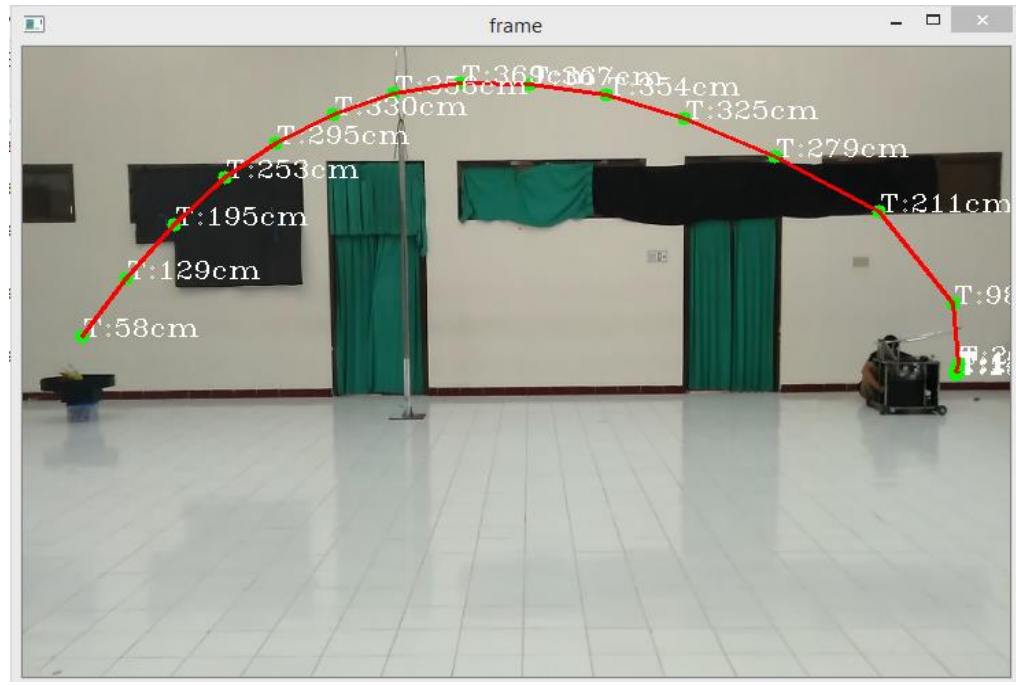

Gambar 14 Pengolahan menggunakan program python ke II

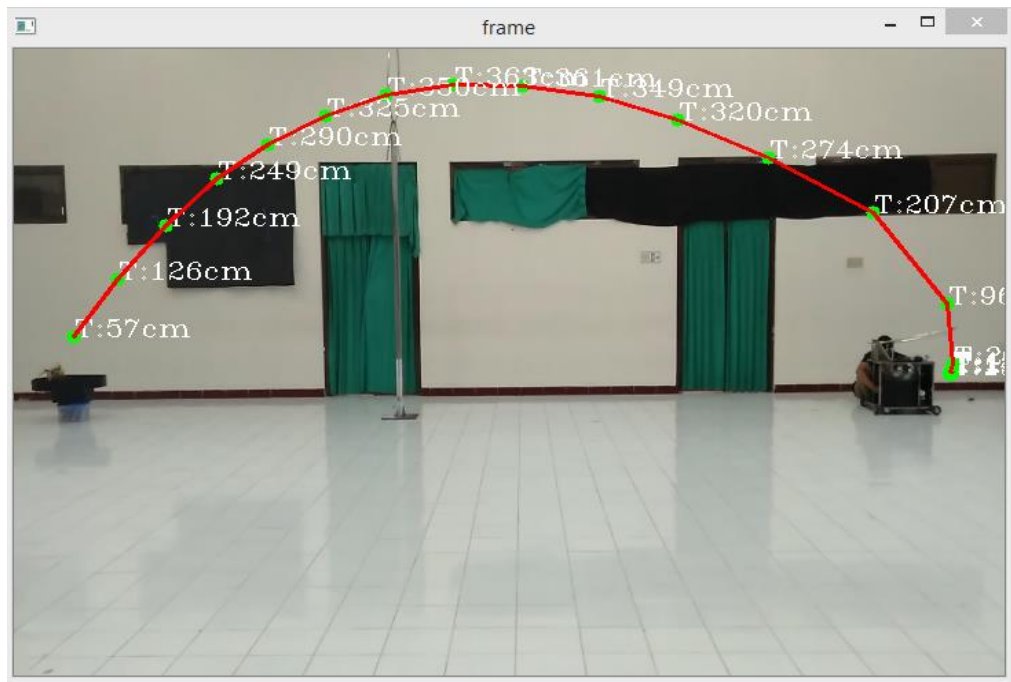

Gambar 15 Pengolahan menggunakan program python ke III. 


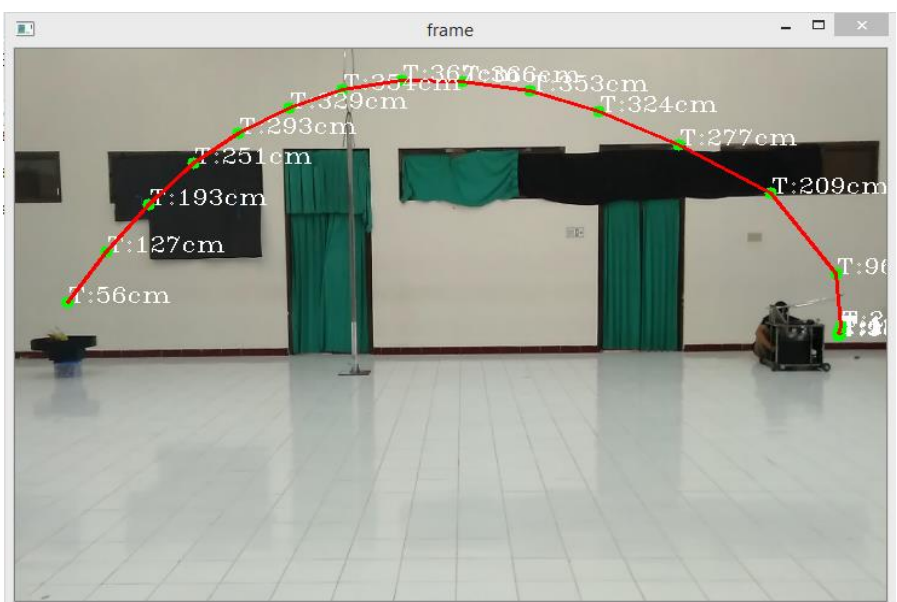

Gambar 16 Pengolahan menggunakan program python ke IV.

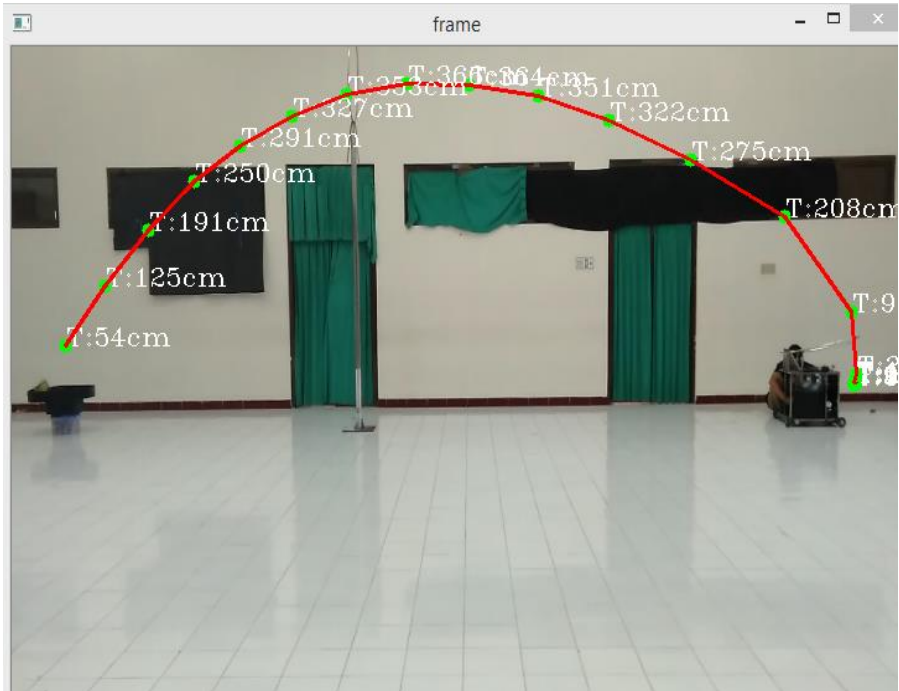

Gambar 17 Pengolahan menggunakan program python ke V.

Hasil perekaman video dengan menggunakan kamera dilihat Gambar 12, Gambar 13, Gambar 14, Gambar 15, dan Gambar 16. Hasil video kemudian diolah dengan perangkat lunak berbasis aplikasi python untuk melihat hasil gerak parabola. Pengujian dilakukan selama 5 kali percobaan menghasilkan jarak, waktu, dan titik tinggi bola berkah. Hasil pengujian lempar bola berkah berikut tabel hasil percobaan Tabel 2 .

Tabel 2. Pengujian data 5 percobaan.

\begin{tabular}{|c|c|c|c|c|c|}
\hline No. & $\begin{array}{c}\text { Sudut Kemiringan } \\
(\text { Derajat })\end{array}$ & $\begin{array}{c}\text { Tekanan Angin } \\
(\text { Kpa/bar })\end{array}$ & $\begin{array}{c}\text { Jarak } \\
(\mathrm{Cm})\end{array}$ & $\begin{array}{c}\text { Waktu } \\
(\mathrm{S})\end{array}$ & $\begin{array}{c}\text { Tinggi } \\
(\mathrm{Cm})\end{array}$ \\
\hline 1. & $0^{\circ}-95^{\circ}$ & 5,9 & 8,80 & 1,67 & 356 \\
\hline 2. & $0^{\circ}-95^{\circ}$ & 5,9 & 8,75 & 1,59 & 349 \\
\hline 3. & $0^{\circ}-95^{\circ}$ & 5,9 & 8,80 & 1,63 & 354 \\
\hline 4. & $0^{\circ}-95^{\circ}$ & 5,9 & 8,80 & 1,66 & 353 \\
\hline 5. & $0^{\circ}-95^{\circ}$ & 5,9 & 8,75 & 1,61 & 350 \\
\hline
\end{tabular}

Pengujian dilakukan dengan tinggi tiang $300 \mathrm{Cm}$ dan jarak $496 \mathrm{Cm}$ selama 5 kali percobaan dengan tekanan angin yang digunakan $5,9 \mathrm{bar} / \mathrm{Kpa}$ dengan sudut kemiringan pelempar $0{ }^{\circ}-95^{\circ}$ dihasilkan lemparan selama 5 kali tepat sasaran pada tiang kedua. Pelempar kedua robot KRAI 2018 menghasilkan pengujian Pelemparan tepat sasaran ke nampan "Rong Bay". Untuk menghasilkan hasil penelitian yang baik maka hasil penelitian akan dibuat rata-rata dengan cara yaitu hasil pengujian dibagi dengan jumlah percobaan Hasil pengujian 5 kali percobaan akan mendapatkan nilai rata-rata hasil pengujian dengan jarak 8,78 m, tinggi 352,4 Cm, waktu 1,63 s dan kecepatan $5,381 \mathrm{~m} / \mathrm{s}$. 


\section{KESIMPULAN}

Tujuan penelitian yang berjudul "Metode Perancangan Pelempar Bola Berkah pada KRAI 2018" untuk memaksimalkan pelempar pada robot KRAI. Berdasarkan analisis dan hasil pengujian dapat diambil kesimpulan. Pengujian pertama dengan sudut kemiringan $0^{\circ}-115^{\circ}$, jarak $7,37 \mathrm{~m}$, tinggi $273,8 \mathrm{Cm}$, waktu 1,42 s dan kecepatan $5,152 \mathrm{~m} / \mathrm{s}$ dapat melemparkan dengan tepat sasaran selama 5 kali percobaan. Hasil pengujian kedua dengan sudut pelempar $0^{\circ}-95^{\circ}$ didapatkan rata - rata jarak $8,78 \mathrm{~m}$, tinggi 352,4 $\mathrm{Cm}$, waktu $1,63 \mathrm{~s}$ dan kecepatan 5,381 m/s. Sudut mekanik $0^{\circ}-95^{\circ}$ dapat melemparkan dengan tepat sasaran, bola berkah dapat masuk ke nampan "rong bay" dengan pengujian 5 kali percobaan.

Disimpulkan bahwa sudut kemiringan mekanik dicondongkan ke depan maka hasil pelemparan akan semakin rendah. Ketika sudut kemiringan dicondongkan ke belakang maka bola berkah akan semakin melambung. Saran untuk sistem pelempar pada robot dirancang selain menggunakan sistem pneumatik karena dalam sistem pneumatik ada beberapa kelemahan. Pelempar pada robot bisa mencoba dengan motor DC. Karena motor DC bisa mendapatkan tegangan yang konstan.

\section{UCAPAN TERIMA KASIH}

Terima kasih kepada editor dan reviewer atas segala saran, masukan dan telah membantu dalam proses penerbitan naskah. Ucapan terima kasih juga ditujukkan kepada pihak-pihak yang telah mendukung penelitian dan memberikan bantuan moral dan material.

\section{REFERENSI}

[1] Agustiawan, “Algoritma Robot Otomatis Pelempar Suttlecock,” Jurnal Inovtek POLBENG, Vol. 3, No. 1, Juni 2018. DOI: $10.35314 /$ isi.v3i1.338

[2] M. Kamaludin and W. S. Aji, "Manuver Robot Manual Menggunakan Pengendali PID pada Robot Manual KRAI 2018," Buletin Ilmiah Sarjana Teknik Elektro, vol. 1, no. 3, pp. 91-99, Desember 2019. DOI: 10.12928/biste.v1i3.978

[3] A. Febriawan and W. S. Aji, "Rotating Control on Robots Indonesian Abu Robot Contest with PID and IMUBN005," Buletin Ilmiah Sarjana Teknik Elektro, vol. 2, no. 1, pp. 14-23, April 2019. DOI: 10.12928/biste.v1i3.987

[4] A. R. Septiadi and S. Amri, "Rancang Bangun dan Analisa Robot Tematik Simulasi Pertanian dengan Kendali Wirelless, ” Jurnal Infomedia Teknik Informatika, Multimedia dan Jaringan, vol. 4, no. 1, pp. 15-20, Juni 2019. DOI: $\underline{10.30811 / j i m . v 4 i 1.916}$

[5] Kanyuma Jitjumnong, Pasapitch Chujai, and Noritsugu Kamata, "Robot Contest for Innovative Development in Education Technology, " International Journal of Mechanical Engineering and Robotics Research, vol. 9, no. 3, pp. 395-400, Maret 2020. Online

[6] B. Arifin, "Analisis Gerak Track Start untuk Memaksimalkan Jarak Lompatan Start pada Renang Ditinjau dari Kajian Biomekanika," Jurnal Kesehatan Olahraga, vol. 2, no. 1, Januari 2014. Online

[7] D. N. Afifah, D. Yulianawati, N. Agustina, R.D.S. Lestari, and M.G. Nugraha, "Metode Sederhana Menentukan Percepatan Gravitasi Bumi Menggunakan Aplikasi Tracker Pada Gerak Parabola Sebagai Media dalam Pembelajaran Fisika Sma," Simposium Nasional Inovasi dan Pembelajaran Sains (SNIP), pp.305-308, Juni 2015. Online

[8] W. Suwito, M. Rif'an, and P. Siwindarto, Pengaturan Posisi Piston Silinder Pneumatik pada Lengan Robot KRAI, 2014, Jurnal Mahasiswa Teknik Elektro Universitas Brawijaya, Vol. 2, No. 1, 2014. Online

[9] I. W. Sutaya, G. S. Santyadiputra, and I. W. Sutaya, "Design of Hexapod Robot Movement Based on Arduino Mega 2560," J. Phys.: Conf. Ser. 1165 012011, 2019. DOI: 10.1088/1742-6596/1165/1/012011

[10] F. S. Rozak and R. Riandini, "Rancang bangun Lengan Robot Pelontar Bola dengan Sistem Pneumatik" ELECTRICES, Vol. 1, No.1, pp. 37-42, Oktober 2019. DOI: 10.32722/ees.v1i1.2305

\section{BIOGRAFI PENULIS}

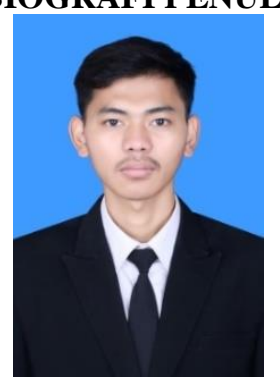

Rochmat Diantoro

Mahasiswa program studi teknik elektro, Universitas Ahmad Dahlan. 


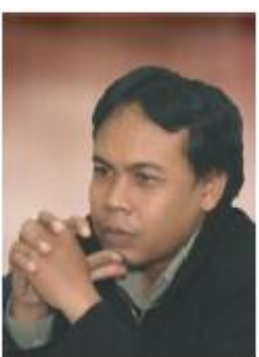

Wahyu Sapto Aji

Dosen program studi teknik elektro universitas ahmad dahlan. 